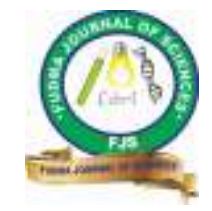

FUDMA Journal of Sciences (FJS)

ISSN online: $2616-1370$

ISSN print: 2645 - 2944

Vol. 4 No. 2, June, 2020, pp 337 - 349

DOI: https://doi.org/10.33003/fjs-2020-0402-132

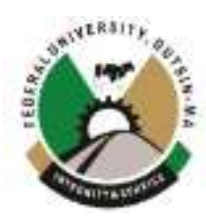

\title{
COMPARISON BETWEEN KELVIN RADII AND BULK HYGROSCOPICITY OF MASS AND VOLUME BASED HYGROSCOPICITY PARAMETER FOR ATMOSPHERIC AEROSOLS
}

\author{
${ }^{1}$ Sa'adu, B., ${ }^{2}$ Tijjani, B. I. and ${ }^{1}$ Bello, S. \\ ${ }^{1}$ Department of Physics, Umaru Musa Yaradua University Katsina. Katsina state, Nigeria. \\ ${ }^{2}$ Department of Physics,Bayero University,Kano.Kano state Nigeria. \\ *Corresponding author's email: bellosaadu5222@gmail.com Phone no: +2347039709888
}

\begin{abstract}
A mass based and volume based hygroscopicities models were applied to the data extracted from Optical Properties of Aerosols and Clouds (OPAC). The microphysical properties obtained were radii, density, refractive index, mass and volume of the atmospheric aerosols of continental average, continental clean, continental polluted, maritime tropical, maritime polluted, maritime clean, at eight different relative humidity of $0 \%, 50 \%$, $70 \%, 80 \%, 90 \%, 95 \%, 98 \%$ and $99 \%$.Using the microphysical properties, hygroscopic growth factors and effective radii of the mixtures were determined while the parameters $A_{v}$ and $B_{v}$ for volume based and $A_{m}$ and $B_{m}$ for mass based of the aerosols were determined using multiple regression analysis with SPSS 16.0 at each relative humidity. Although it was discovered that $B_{v}$ is more dominant than $A_{v}$, the $R^{2}$ for all the models are greater than $90 \%$. The significances are less than $0.05, A_{m}>A_{v}$ and $B_{m}<B_{v}$, therefore the two models are good for atmospheric modeling.
\end{abstract}

Keywords: Hygroscopicity, volume based, mass based, atmospheric aerosols, OPAC.

\section{INTRODUCTION}

Hygroscopicity is the ability of aerosol particles to absorb water as a major property, which can change the particle size, shape, and optical properties (Ogren and Charlson, 1992; Tang, 1996), sometimes cause visibility deterioration (Liu et al., 2013), and thus control direct and indirect climate effects of the atmospheric aerosols. For a given size of the particles, the hygroscopic behaviors can also reflect information on their ageing process, mixing state (Maßling et al., 2003; Wang et al., 2017) and even the ability of the particles to be activated as cloud condensation nuclei, CCN (Kawana et al., 2014; Zhang et al., 2014, 2017).

Atmospheric aerosols can affect climate directly by scattering and absorbing incoming solar radiation, or indirectly by acting as cloud condensation nuclei (CCN), which form clouds and in turn can reflect light (Twomey, 1977).

The efficiency of particles as CCN also affects both aerosol particle and cloud droplet lifetimes. It is well recognized that these effects represent one of the largest uncertainties in assessing the changes in radiative forcing from pre-industrial times to the present (Solomon et al., 2007). As such, understanding the hygroscopic properties of aerosols and the processes that govern cloud droplet activation are important.

K"ohler theory has been used to predict the CCN-activity of inorganic compounds for many years (K*ohler, 1936). In the last decade, the focus has turned to the prediction of the $\mathrm{CCN}$ activity of organic compounds in atmospheric particles. Laboratory studies have shown that the CCN- activity of organic, inorganic, or mixed aerosol systems can be predicted if the composition of the particles is well- characterized and their properties are known (Bilde and Svenningsson, 2004; Broekhuizen et al., 2004a; Raymond and Pandis, 2002, 2003).

However, ambient aerosols are composed of numerous organic compounds that are difficult to identify and quantify (Jacobson et al., 2000; Saxena and Hildemann, 1996), therefore complicating the prediction of the $\mathrm{CCN}$-activity of those ambient particles. The organic fraction comprises a significant fraction of the aerosol at many locations in the Northern Hemisphere (Zhang et al., 2007), highlighting the need to study organic aerosol hygroscopicity.

A mass-based hygroscopicity parameter $\mathrm{km}$ was introduced building on the single hygroscopicity parameter of Petters and Kreidenweis (2007), and developed a $\mathrm{km}$-interaction model (KIM) to describe non-ideal solution behavior and concentration dependencies of single- and multi component systems. The KIM was demonstrated to capture and reproduce the characteristics of water uptake by pure reference substances as well as atmospheric aerosol samples under sub- and super saturated conditions (Mikhailov et al, 2011).

\section{METHODOLOGY}

The data extracted from Optical Properties of Aerosols and clouds are presented below where the insoluble component describes soil particles that also contain organic compounds, but do not experience hygroscopic growth while water-soluble component combines all aerosol particles that originate in gas to 
particle conversion (including various kinds of sulfates, nitrates, and also organic substances). The soot component describes the absorbing black carbon. The sea salt components are given for the accumulation $(100 \mathrm{~nm}<\mathrm{D}<1 \mu \mathrm{m})$ and the coarse $(\mathrm{D}>1 \mu \mathrm{m})$ mode separately and both are dependent on RH. (Zieger et al,
2013).Water soluble components (WASO, consists of scattering aerosols), water insoluble (INSO), soot (SOOT) not soluble in water, ssam and sscm are Sea-salt accumulation and coarse modes particles that consist of the various kinds of salt contained in seawater.( Tijjani et al,2015)

Table1: the composition and some microphysical properties of atmospheric aerosols extracted from OPAC at ORHs (Hess et al, 1998)

\begin{tabular}{|c|c|c|c|c|c|c|c|}
\hline $\begin{array}{l}\text { Model } \\
\text { No. }\end{array}$ & $\begin{array}{l}\text { Aerosols } \quad \text { Model } \\
\text { Types }\end{array}$ & $\begin{array}{l}\text { Aerosols } \\
\text { Components }\end{array}$ & $\begin{array}{l}\text { Number of Conc. } \\
\left(\mathrm{cm}^{-3}\right)\end{array}$ & $\begin{array}{l}\mathrm{Rmin} \\
(\mu \mathrm{m})\end{array}$ & $\begin{array}{l}\operatorname{Rmax} \\
(\mu \mathrm{m})\end{array}$ & $\begin{array}{l}\text { Sigma } \\
\sigma\end{array}$ & $\begin{array}{l}\text { Rmod } \\
(\mu \mathrm{m})\end{array}$ \\
\hline \multirow{3}{*}{1} & \multirow{3}{*}{ Continental Average } & Inso & 0.4000 & 0.0050 & 20.0000 & 2.5100 & 0.4710 \\
\hline & & Waso & $7,000.0000$ & 0.0050 & 20.0000 & 2.2400 & 0.0212 \\
\hline & & Soot & $8,300.0000$ & 0.0050 & 20.0000 & 2.0000 & 0.0118 \\
\hline \multirow{2}{*}{2} & \multirow{2}{*}{ Continental Clean } & Waso & $2,600.0000$ & 0.0050 & 20.0000 & 2.2400 & 0.0212 \\
\hline & & Inso & 0.1500 & 0.0050 & 20.0000 & 2.5100 & 0.4710 \\
\hline \multirow{3}{*}{3} & \multirow{3}{*}{ Continental Polluted } & Inso & 0.6000 & 0.0050 & 20.0000 & 2.5100 & 0.4710 \\
\hline & & Waso & $15,700.0000$ & 0.0050 & 20.0000 & 2.2400 & 0.0212 \\
\hline & & Soot & $34,300.0000$ & 0.0050 & 20.0000 & 2.0000 & 0.0118 \\
\hline \multirow{3}{*}{4} & \multirow{3}{*}{ Maritime Clean } & Waso & $1,500.0000$ & 0.0050 & 20.0000 & 2.2400 & .0212 \\
\hline & & Ssam & 20.0000 & 0.0050 & 20.0000 & 2.0300 & 0.2090 \\
\hline & & Sscm & 0.0032 & 0.0050 & 60.0000 & 2.0300 & 1.7500 \\
\hline \multirow{4}{*}{5} & \multirow{4}{*}{ Maritime Polluted } & Waso & $3,800.0000$ & 0.0050 & 20.0000 & 2.2400 & 0.0212 \\
\hline & & Soot & $5,180.0000$ & 0.0050 & 20.0000 & 2.0000 & 0.0118 \\
\hline & & Ssam & 20.0000 & 0.0050 & 20.0000 & 2.0300 & 0.2090 \\
\hline & & Sscm & 0.0032 & 0.0050 & 60.0000 & 2.0300 & 1.7500 \\
\hline \multirow{3}{*}{6} & \multirow{3}{*}{ Maritime Tropical } & Waso & 590.0000 & 0.0050 & 20.0000 & 2.2400 & 0.0212 \\
\hline & & Ssam & 10.0000 & 0.0050 & 20.0000 & 2.0300 & 0.2090 \\
\hline & & $\mathrm{Sscm}$ & 0.0013 & 0.0050 & 60.0000 & 2.0300 & 1.7500 \\
\hline
\end{tabular}

Volume based Kelvin radii and bulk hygroscopicity factor

The kohler theory is given by

$s_{w}=a_{w} \exp \left(\frac{4 \sigma_{w V_{w}}}{R T D}\right)----------(1)$

Where, aw is water activity, $\sigma_{w}$ is the surface tension, $V_{w}$ is the molar volume $R$ is the universal gas constant, $T$ is the temperature and D is the diameter( Pruppacher and Klett, 2000; Seinfeld and Pandis, 2006).

According to petters and kreidenweis (2007), the hygroscopic growth of aerosol particle can be efficiently approximated by a simplified version of eq.(1), Since there is a good relation between density of water, mass and its molar volume. Eq (1) can be written as the so-called $\mathrm{k}_{\mathrm{v}}$-kohler equation:

$$
\begin{gathered}
s_{w}=a_{w} \exp \left(\frac{4 \sigma_{w M_{w}}}{R T \rho_{w} D}\right)---------(2) \\
s_{w}=\left[\frac{k_{v}}{g^{3}-1}+1\right]^{-1}\left(\frac{4 \sigma_{w M_{W}}}{R T P_{W} D}\right)--------(3)
\end{gathered}
$$

Where $\mathrm{a}_{\mathrm{w}}$ is the volume based water activity and is define as

$a_{w}=\left[\frac{k_{v}}{g^{3}-1}+1\right]^{-1}-----------(4)$

The aerosol's hygroscopicity growth factor g(s),(swietlicki et al.,2008;randles,et al.,2004) is define as: 
$g(s)=\frac{r(s)}{r(s=0)}------------(5)$

Where S can be set for eight values, at $0 \%, 50 \%, 70 \%, 80 \%, 90 \%, 95 \%, 98 \%$ and $99 \%$ relative humidity RH substituting eqn (5) in to eqn (3) we get

$\ln S=\frac{A}{r(S)}+\frac{B}{1-(g(s))^{3}}----------(6)$

Where $r_{K}=\frac{2 \sigma v_{w}}{R T}=A$ and $B=v \emptyset \frac{v_{w}}{v_{s}}$ are assumed to be constant, $\mathrm{r}(\mathrm{s})$ and $\mathrm{r}(\mathrm{s}=0)$ are the radii of the mixture or the volume equivalent radii of the wet and dry mixtures respectively, $\sigma$ is the surface tension, $v_{w}$ and $v_{s}$ are the coefficient. The product of $v$ and $\emptyset$ is equivalent to the so called van't Hoff factor (Tijjani et al,2015).

The first term on the right hand side of equation (6) is

$$
\ln K_{e}=\frac{2 \sigma \vartheta_{w}}{R \operatorname{Rr}(S)}=\frac{A}{r(S)}=g_{\sigma}(r(S))---------(7)
$$

Where a characteristic length for the effect of surface tension (or Kelvin radius) $r_{K}=\frac{2 \sigma \vartheta_{w}}{R T}=A$.The Kelvin effect is small for large droplet radii and It becomes very large for radii $r(s)$ smaller than the Kelvin radius $r_{k}$

The Second term on the right hand side of equation (6) is

$\ln a_{w}=\frac{B}{1-(g(s))^{3}}------------(8)$

But generally atmospheric aerosols usually comprised mixtures of soluble components, therefore the information on the hygroscopicity modes was merged into an "over-all" or "bulk" or "effective" hygroscopic growth factor of the mixture, geff (s) representative for the entire aerosols particle population as:

$g_{\text {eff }}(S)=\left(\sum_{k} x_{k} g_{k}^{3}(S)\right)^{1 / 3}-----------(9)$

The effective or volume equivalent radius of the mixture was determined using the relation

$r_{e f f}(S)=\left(\sum_{k} x_{k} r_{k}^{3}\right)^{1 / 3}------------(10)$

Where the summation is performed over all compounds present in the particles and $\mathrm{X}_{\mathrm{k}}$ represent their respective volume fractions, using the Zdanovskii-Stokes-Robisnson relation (ZSR relation; Sjogren et al., 2007; Stokes and Robinson, 1966;Meyer et al., 2009; Stock et al., 2011) .

Equations (6) can be written in terms of volume based as

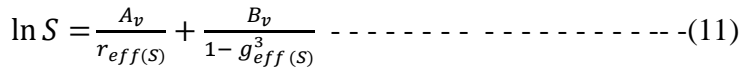

The Kelvin effect and water activity are the major parameters that made hygroscopic growth of aerosols to be size and composition dependent and are given by

$$
\begin{aligned}
& k_{e}=\exp \left(\frac{A_{v}}{r_{e f f}}\right)---------(12) \\
& a_{w}=\exp \left(\frac{B_{v}}{1-g_{e f f}^{3}}\right)----------(13)
\end{aligned}
$$

Where $A_{v}$ is kelvin radii and $B_{v}$ is bulk hygroscopicity of volume based hygroscopicity. and can be determine using regression analysis with SPSS 16.0.

Mass Based Hygroscopicity kelvin radii and bulk hygroscopicity factor

In analogy to the volume based hygroscopicity we define a mass based hygroscopicity as

$\ln S=\frac{A_{m}}{\left(g_{m}\right)^{1 / 3}}+\frac{B_{m}}{1-g_{m}}--------(14)$

Where $A_{m}$ is the kelvin radii and $B_{m}$ is the bulk hygroscopicity of mass based. Using multiple regression analysis with SPSS 16.0 for windows, the constants $A_{m}$ and $B_{m}$ were determined.

The first term on the right hand side of equation (14) can be written as

$$
\ln k_{e}=\frac{2 \sigma \vartheta_{w}}{R T\left(g_{m}\right)^{1 / 3}}=\frac{A_{1}}{\left(g_{m}\right)^{1 / 3}}--------(15 a)
$$

This implies that

$$
k_{e}=\exp \left(\frac{A_{1}}{\left(g_{m}\right)^{1 / 3}}\right)----------(15 b)
$$

The second term on the right hand side of equation (14) is

$$
\ln a_{w}=\frac{B_{1}}{1-g_{m}}-----------(16 a)
$$

This implies

$$
a_{w}=\exp \left(\frac{B_{1}}{1-g_{m}}\right)-----------(16 b)
$$

By defining the mass growth factor $\mathrm{G}_{\mathrm{m}}$ (Mikhailov et al, 2011) as 
$G_{m}=\frac{m_{w}+m_{d}}{m_{d}}------------(17)$

Where $m_{d}$ is the mass of the dry particle material and $m_{w}$ is the mass of water in the wet particle (aqueous droplet).

\section{Results and Discussion}

From the result below, it can be seen that, based on the values of $\mathrm{R}^{2}$, that the data fitted the equation very excellent. By analysing the table, it can be seen that B is more dominant than A for maritime clean, maritime polluted and maritime tropical due to their $\mathrm{p}$ values and from the values of Kelvin radii, it observed that, the values of Kelvin radii are less than the values of bulk hygroscopicity and Kelvin radii have higher values in maritime clean and maritime tropical than maritime polluted, continental average, continental clean and continental polluted.

Table 2: The results of Kelvin radii and bulk hygroscopicity for volume based using equation(11)

\begin{tabular}{|l|l|l|l|l|l|l|l|}
\hline $\mathrm{s} / \mathrm{n}$ & Aerosols M & $\begin{array}{l}\text { Kelvin } \\
\text { radii }\left(\mathrm{A}_{\mathrm{v}}\right)\end{array}$ & $\mathrm{p}$-value & bulk hygroscopicity $\left(\mathrm{B}_{\mathrm{v}}\right)$ & $\mathrm{p}$-value & $\mathrm{R}^{2}$ & significance \\
\hline 1 & $\begin{array}{l}\text { Continental } \\
\text { average }\end{array}$ & 0.00623 & 0.03362 & 0.4005 & $3.09 \mathrm{E}-07$ & 0.99729 & $4.72 \mathrm{E}-06$ \\
\hline 2 & $\begin{array}{l}\text { continental } \\
\text { clean }\end{array}$ & 0.00655 & 0.03504 & 0.41251 & $4.02 \mathrm{E}-07$ & 0.99698 & $5.87 \mathrm{E}-06$ \\
\hline 3 & $\begin{array}{l}\text { continental } \\
\text { polluted }\end{array}$ & 0.00618 & 0.03703 & 0.43287 & $6.07 \mathrm{E}-07$ & 0.99642 & $8.22 \mathrm{E}-06$ \\
\hline 4 & Maritime Clean & 0.05123 & 0.08021 & 2.14803 & $3.37 \mathrm{E}-05$ & 0.98928 & $7.39 \mathrm{E}-05$ \\
\hline 5 & $\begin{array}{l}\text { Maritime } \\
\text { Polluted }\end{array}$ & 0.04812 & 0.07925 & 1.99641 & $2.81 \mathrm{E}-05$ & 0.99016 & $6.23 \mathrm{E}-05$ \\
\hline 6 & $\begin{array}{l}\text { maritime } \\
\text { tropical }\end{array}$ & 0.0499 & 0.07798 & 2.17642 & $3.55 \mathrm{E}-05$ & 0.9892 & $7.51 \mathrm{E}-05$ \\
\hline
\end{tabular}

From the result in table below, it can be seen that maritime clean, maritime polluted and maritime tropical has high values of kelvin radii due to the dominant of sea salt.

Table 3: the results of kelvin radii and bulk hygroscopicity for mass based using eqn(14)

\begin{tabular}{|c|c|c|c|c|c|c|c|}
\hline $\mathrm{s} / \mathrm{n}$ & Aerosols model & $\begin{array}{l}\text { Kelvin } \\
\operatorname{radii}\left(\mathrm{Am}_{\mathrm{m}}\right)\end{array}$ & p-values & Bulk hygroscopicity $\left(\mathrm{B}_{\mathrm{m}}\right)$ & p-values & $\mathrm{R}^{2}$ & Significance \\
\hline 1 & continental average & 0.6556 & $2.60 \mathrm{E}-05$ & 0.1302 & $1.14 \mathrm{E}-07$ & 0.9991 & 5.01E-07 \\
\hline 2 & continental clean & 0.6696 & $2.68 \mathrm{E}-05$ & 0.1327 & $1.25 \mathrm{E}-07$ & 0.9991 & $5.41 \mathrm{E}-07$ \\
\hline 3 & continental polluted & 0.7615 & $3.36 \mathrm{E}-05$ & 0.1489 & 2.32E-07 & 0.9988 & 8.87E-07 \\
\hline 4 & $\begin{array}{l}\text { maritime } \\
\text { clean }\end{array}$ & 1.3054 & 0.0001 & 0.2474 & $4.06 \mathrm{E}-06$ & 0.9963 & $8.86 \mathrm{E}-06$ \\
\hline 5 & maritime polluted & 3.2413 & 0.0014 & 0.7551 & 0.0002 & 0.9936 & 0.0003 \\
\hline 6 & maritime tropical & 3.3776 & 0.0005 & 0.8058 & $6.48 \mathrm{E}-05$ & 0.9910 & $5.20 \mathrm{E}-05$ \\
\hline
\end{tabular}


Table 4 shows that the mass growth factor increases as the relative humidity increases but there is much increments for maritime clean, maritime polluted and maritime tropical at the liquescence point (98\% -99\%).

Table 4.The mass growth factor $G_{m}$ using $\operatorname{eqn}(17)$

\begin{tabular}{|l|r|r|r|r|r|r|r|}
\hline Aerosols model & \multicolumn{1}{|l|}{$\mathrm{RH}(0.5)$} & $\mathrm{RH}(0.7)$ & $\mathrm{RH}(0.8)$ & $\mathrm{RH}(0.9)$ & $\mathrm{RH}(0.95)$ & $\mathrm{RH}(0.98)$ & $\mathrm{RH}(0.99)$ \\
\hline continental average & 1.237 & 1.385 & 1.543 & 1.921 & 2.525 & 3.776 & 5.032 \\
\hline continental clean & 1.242 & 1.393 & 1.555 & 1.940 & 2.558 & 3.835 & 5.118 \\
\hline continental polluted & 1.276 & 1.448 & 1.632 & 2.071 & 2.775 & 4.230 & 5.691 \\
\hline maritime tropical & 2.288 & 2.997 & 3.774 & 5.921 & 9.853 & 20.291 & 34.461 \\
\hline maritime polluted & 2.145 & 2.769 & 3.464 & 5.338 & 8.788 & 17.742 & 29.857 \\
\hline maritime clean & 2.272 & 2.959 & 3.728 & 5.811 & 9.685 & 19.836 & 33.728 \\
\hline
\end{tabular}

Table 5 shows that, the effective hygroscopic growth of the aerosols don't depend on the initial values of relative humidity. By comparing table 1 with the effective hygroscopic growth of the aerosols at $0 \%$, it can be observe that they depend on the nature of the compositions.

Table 5.the hygroscopic growth factor geff using equation (9)

\begin{tabular}{|l|l|l|l|l|l|l|l|l|l|}
\hline $\mathrm{s} / \mathrm{n}$ & $\begin{array}{l}\text { aerosols } \\
\text { model }\end{array}$ & $\mathrm{RH}(0)$ & $\mathrm{RH}(0.5)$ & $\mathrm{RH}(0.7)$ & $\mathrm{RH}(0.8)$ & $\mathrm{RH}(0.9)$ & $\mathrm{RH}(0.95)$ & $\mathrm{RH}(0.98)$ & $\mathrm{RH}(0.99)$ \\
\hline 1 & $\begin{array}{l}\text { continental } \\
\text { average }\end{array}$ & 1 & 1.164 & 1.262 & 1.358 & 1.559 & 1.809 & 2.188 & 2.471 \\
\hline 2 & $\begin{array}{l}\text { continental } \\
\text { clean }\end{array}$ & 1 & 1.169 & 1.268 & 1.364 & 1.565 & 1.815 & 2.193 & 2.475 \\
\hline 3 & $\begin{array}{l}\text { continental } \\
\text { polluted }\end{array}$ & 1 & 1.176 & 1.277 & 1.374 & 1.575 & 1.824 & 2.200 & 2.481 \\
\hline 4 & $\begin{array}{l}\text { maritime } \\
\text { clean }\end{array}$ & 1 & 1.589 & 1.788 & 1.967 & 2.351 & 2.864 & 3.797 & 4.722 \\
\hline 5 & $\begin{array}{l}\text { Maritime } \\
\text { Polluted }\end{array}$ & 1 & 1.560 & 1.755 & 1.933 & 2.312 & 2.819 & 3.744 \\
\hline 6 & $\begin{array}{l}\text { Maritime } \\
\text { Tropical }\end{array}$ & 1 & 1.593 & 1.792 & 1.972 & 2.357 & 2.871 & 4.665 \\
\hline
\end{tabular}

From table 6 below, it can be seen that the effective radii of the aerosols decreases as the relative humidity increase for continental average, continental clean and continental polluted while it increases as relative humidity increases for maritime clean, maritime polluted and maritime tropical due to their compositions.

Table 6. The effective radius $r_{\text {eff }}$ of the aerosols using equation (10)

\begin{tabular}{|c|c|c|c|c|c|c|c|c|c|}
\hline $\mathrm{s} / \mathrm{n}$ & $\begin{array}{l}\text { aerosols } \\
\text { model }\end{array}$ & $\mathrm{RH}(0)$ & $\mathrm{RH}(0.5)$ & $\mathrm{RH}(0.7)$ & $\mathrm{RH}(0.8)$ & $\mathrm{RH}(0.9)$ & $\mathrm{RH}(0.95)$ & $\mathrm{RH}(0.98)$ & $\mathrm{RH}(0.99)$ \\
\hline 1 & $\begin{array}{l}\text { continental } \\
\text { average }\end{array}$ & 0.362 & 0.320 & 0.303 & 0.287 & 0.260 & 0.232 & 0.198 & 0.179 \\
\hline 2 & $\begin{array}{l}\text { continental } \\
\text { clean }\end{array}$ & 0.368 & 0.325 & 0.306 & 0.290 & 0.262 & 0.233 & 0.200 & 0.180 \\
\hline 3 & $\begin{array}{l}\text { continental } \\
\text { polluted }\end{array}$ & 0.329 & 0.288 & 0.271 & 0.256 & 0.231 & 0.205 & 0.175 & 0.158 \\
\hline 4 & maritime clean & 0.593 & 0.788 & 0.830 & 0.862 & 0.924 & 0.991 & 1.103 & 1.220 \\
\hline 5 & $\begin{array}{l}\text { maritime } \\
\text { polluted }\end{array}$ & 0.552 & 0.762 & 0.804 & 0.838 & 0.901 & 0.970 & 1.084 & 1.204 \\
\hline 6 & $\begin{array}{l}\text { maritime } \\
\text { tropical }\end{array}$ & 0.561 & 0.744 & 0.783 & 0.816 & 0.875 & 0.944 & 1.061 & 1.187 \\
\hline
\end{tabular}




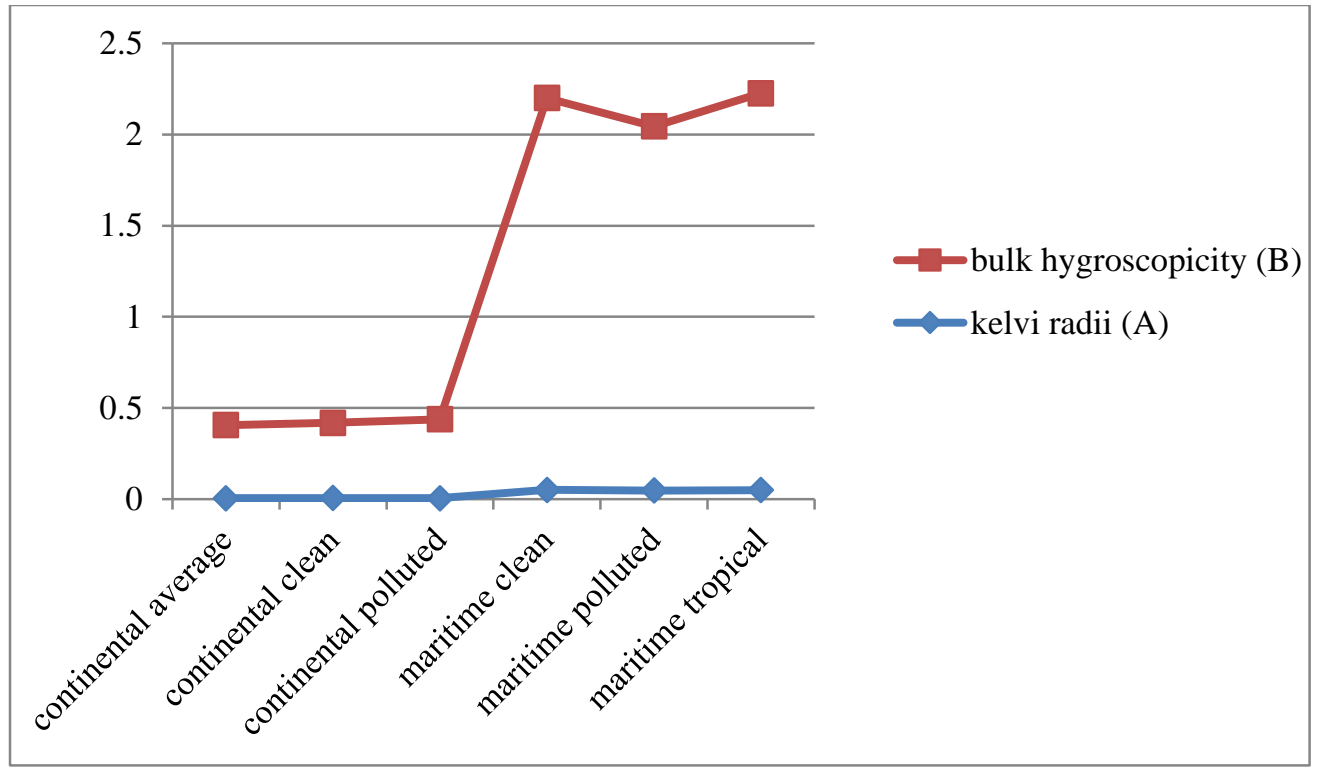

Figure 1: a graph of bulk hygroscopicity $(B)$ and kelvin radii $(A)$ for volume based

From the graph above, it can be seen that bulk hygroscopicity and kelvin radii shows good linear relationship in continental average, continental clean and continental polluted while continental clean, continental average and continental polluted lies between 0-0.5 and maritime clean, maritime polluted and maritime tropical also lies between 2-2.5.

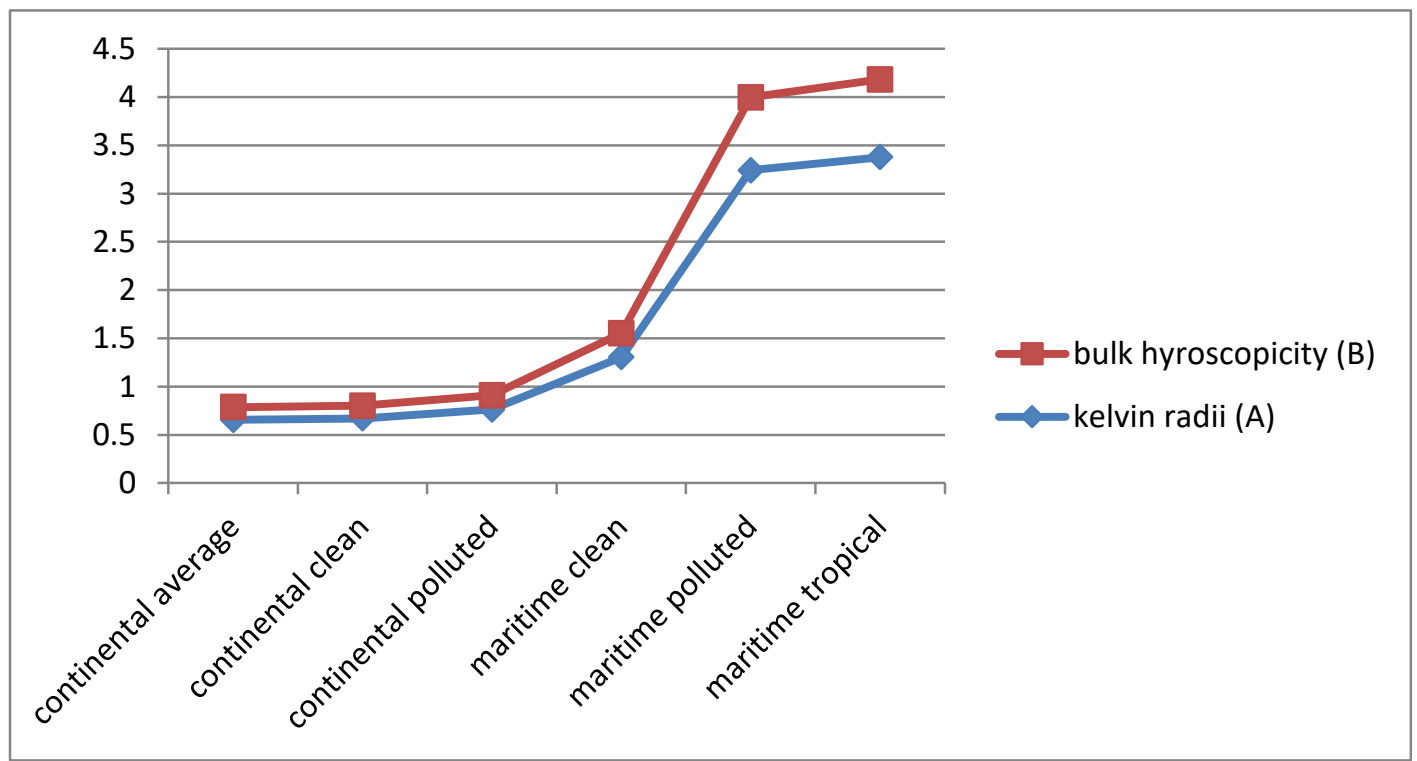

Figure 2: A graph of kelvin radii (A) and bulk hygroscopicity (B) for mass based

According to the graph above, it shows that; there are good agreement between continental clean, continental average and continental polluted while maritime polluted and maritime tropical has deviated. By observing maritime tropical,it can be seen that it rises very high in the graph than the remaining aerosols component and also continental clean and continental average lies at the same level. 


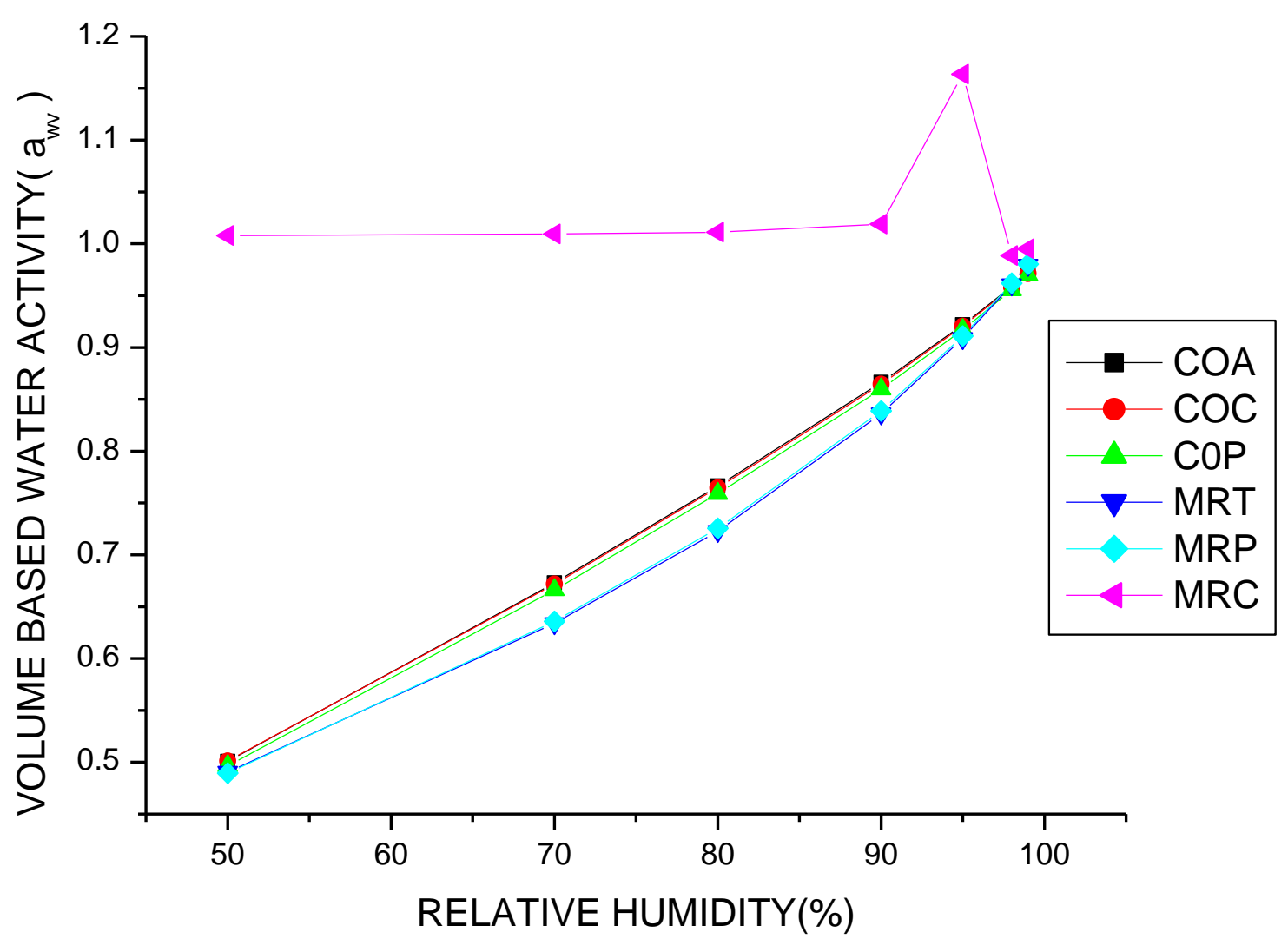

Figure 3: A graph of volume based water activity against relative humidity using eqn(13)

From figure 3, the relative humidity is used to analyze how the water activity of the volume based affects the ambient RH for the aerosols. It is clearly seen that, the water activity lowers the ambient relative humidity of Maritime pollution and Maritime tropical while the Continental pollution, Continental clean and Continental average raises. The maritime clean show linearity except at one point. 


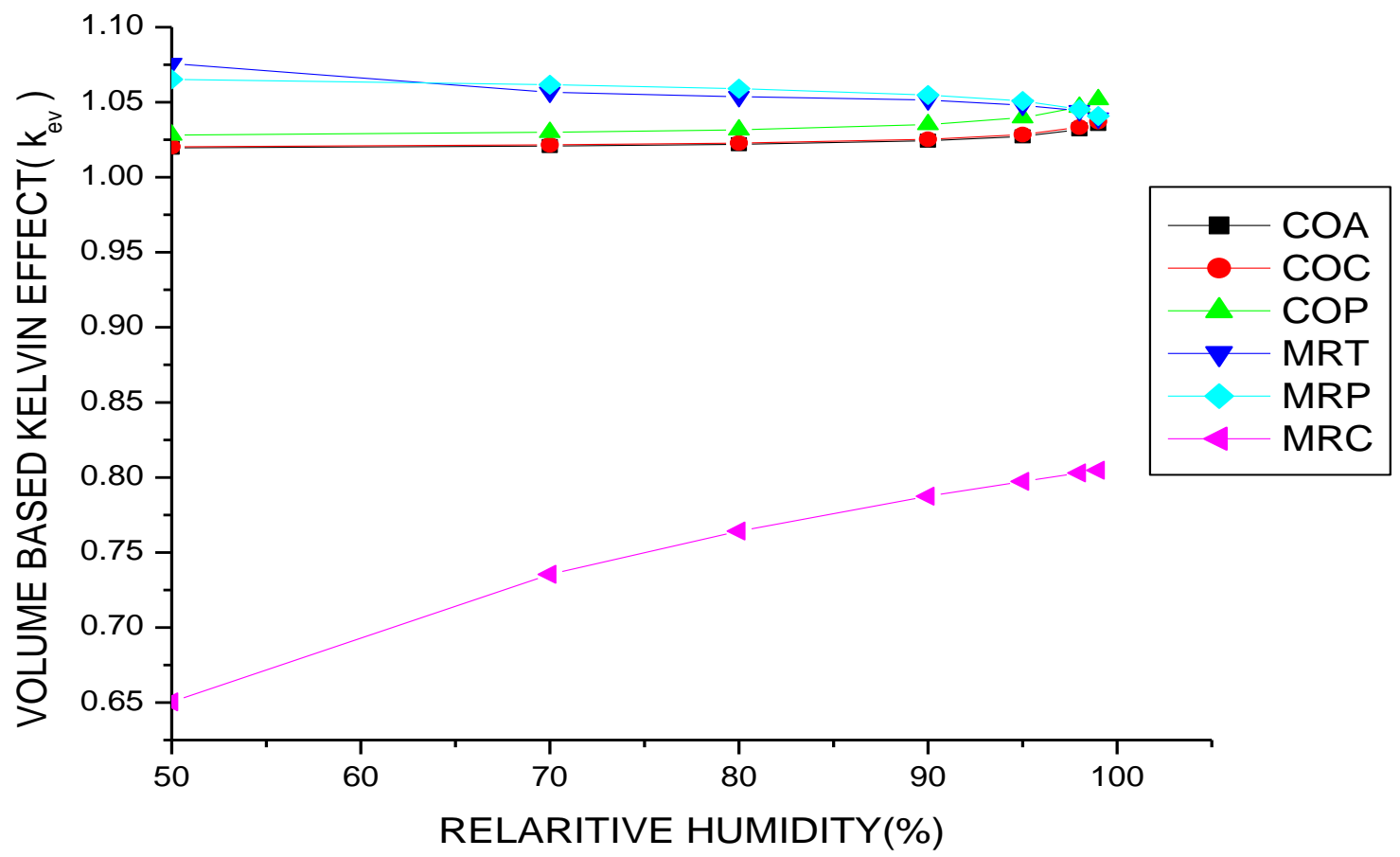

Figure 4: A graph of volume based kelvin effect against Relative Humidity using eqn (12)

From figure 4, it can be seen that volume based Kelvin effect on Maritime clean is more sensitive to RH although the sensitivity increase with increase in RH in a non-linear form and is less than, while Continental polluted, continental clean are also independent of RH but greater than one. Secondly, The Maritime tropical and Maritime polluted have the same type of behaviour, that is why they increase slightly with the increase in RH and are slightly more sensitive at higher RHs (90\% - 99\%). 


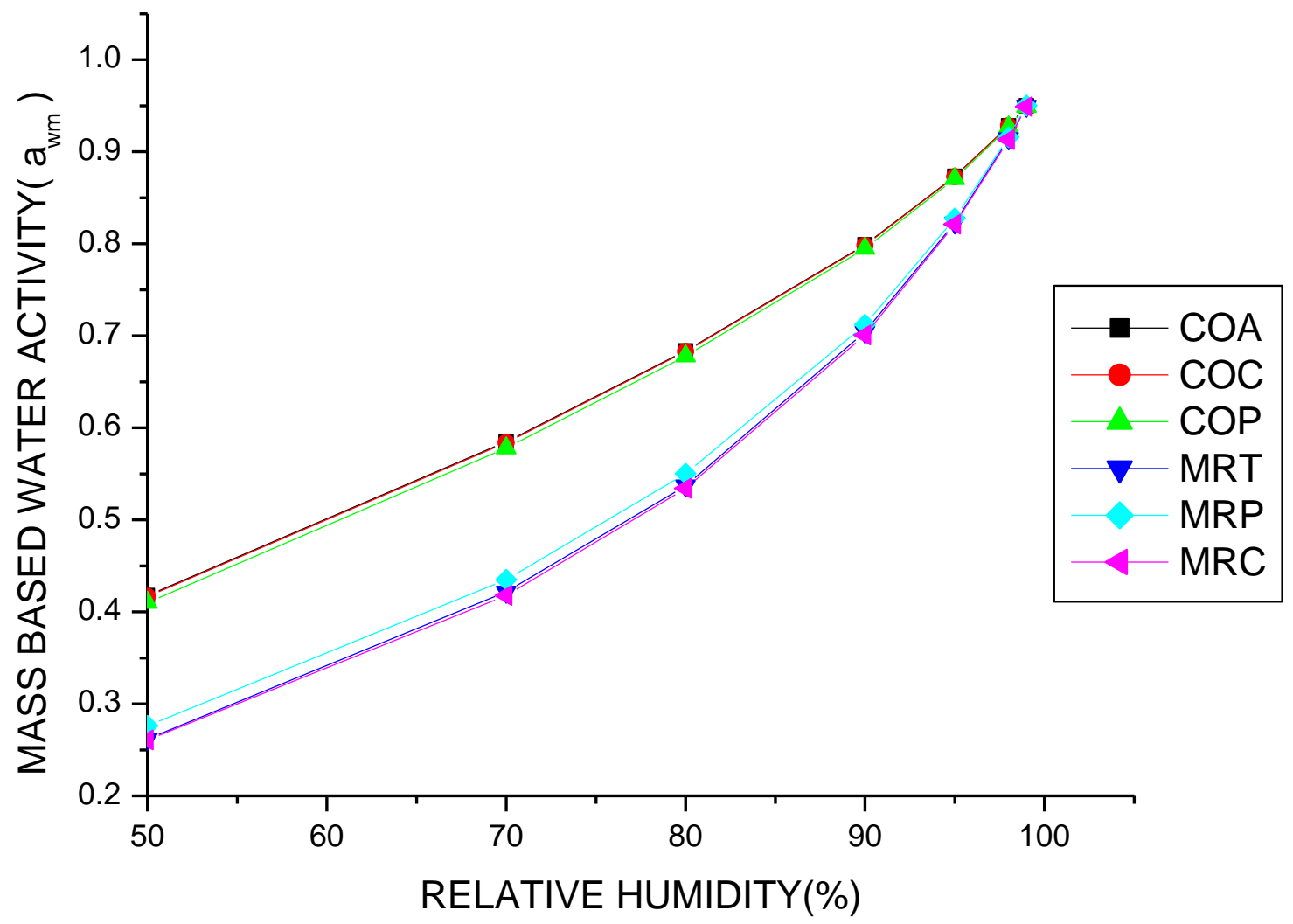

Figure 5: A graph of mass based water activity against relative humidity usingeqn(16b)

The ambient relative humidity is used to compare how the mass based affect the water activity of atmospheric aerosols. It can also see from the above graph show that the water activity lowers the ambient relative humidity for maritime polluted, maritime clean and maritime tropical. The continental clean, continental average rises. 


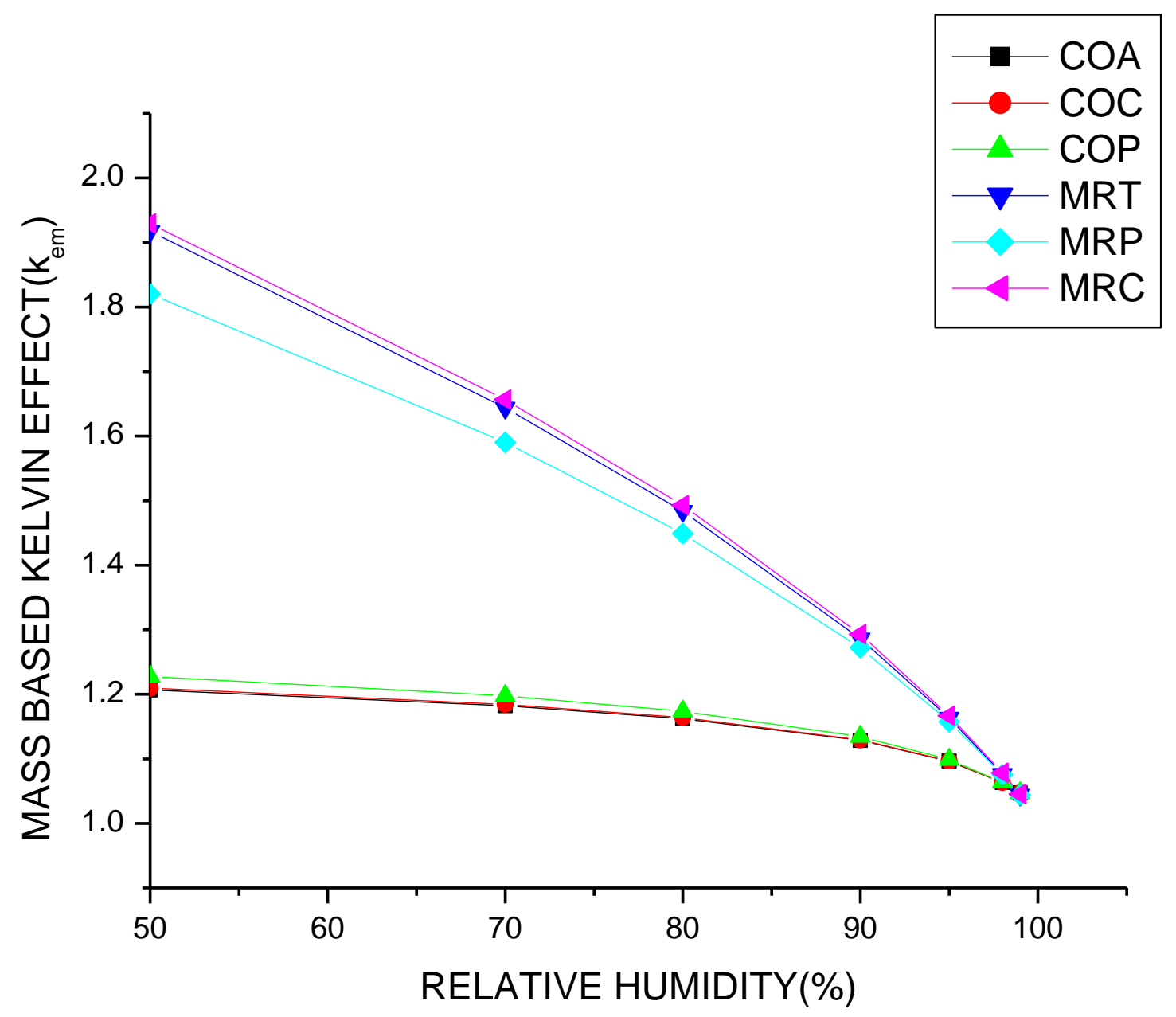

Figure 6: A graph of mass based kelvin effect against relative humidity using eqn (15b)

According to the graph above it can seen that, the entire aerosols component shows curve and maritime tropical and maritime clean and maritime pollued rises while continental clean and continental average and continental polluted has lower the relative humidity. 


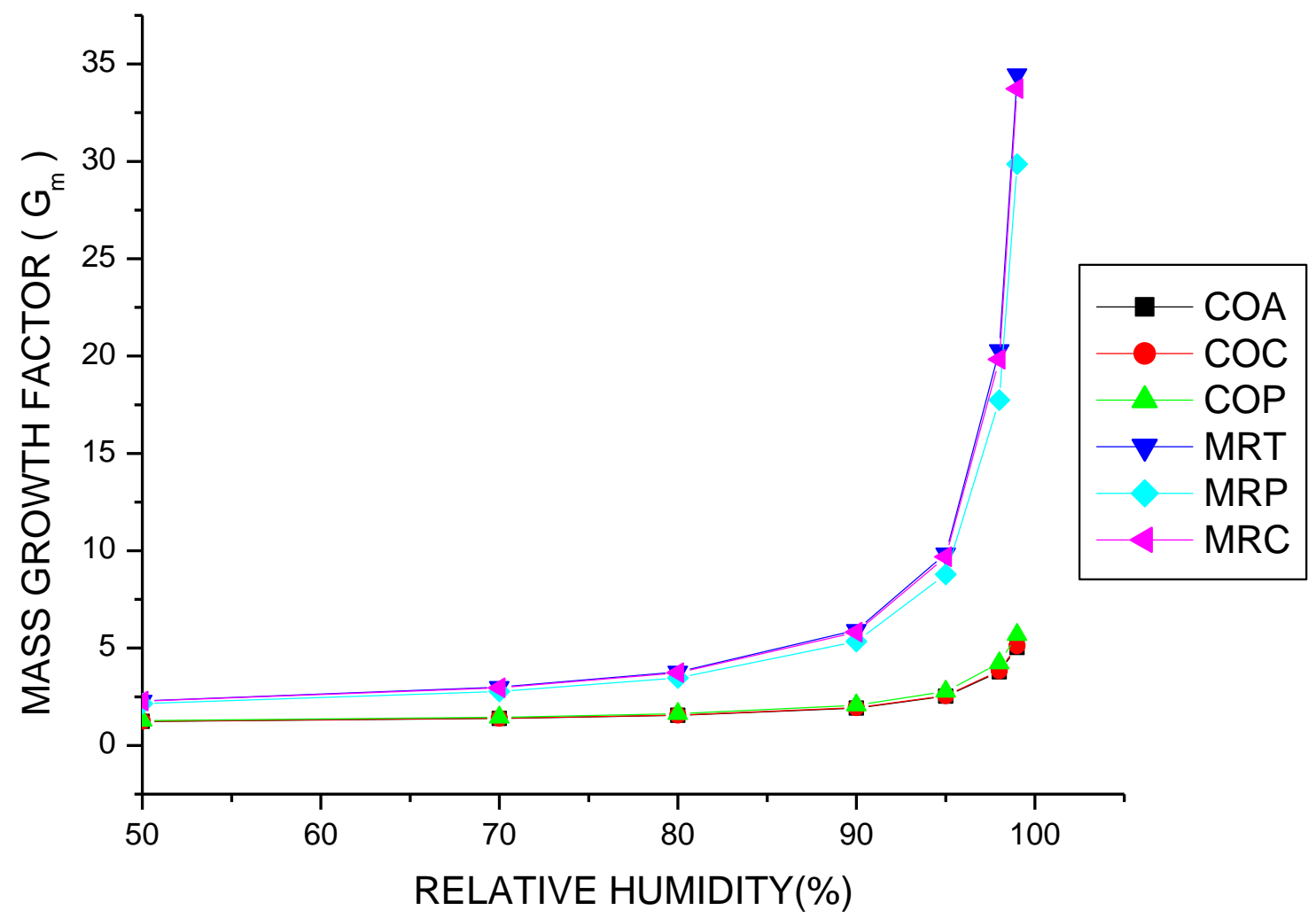

Figure 7: A graph of mass grow factor against relative humidity using eqn (17)

Figure 7 shows that, the mass growth has less effect at high relative humidity and shows steep curve at deliquescence point (90\% to $99 \%$ ) of the all aerosols. They are more sensitive at deliquescence point; however there is slight increase of the mass growth of the particle at low relative humidity, meaning the particle at this region are more hygroscopic in nature.

\section{CONCLUSION}

The result obtained shows that bulk hygroscopicity (B) is more dominant than Kelvin radii (A) for maritime clean, maritime polluted and maritime tropical due to their p-value for volume based. From table 4,it shows that the mass growth factor $\left(\mathrm{G}_{\mathrm{m}}\right)$ increases as the relative humidity increases but there are much increment for maritime clean and maritime polluted at deliquescence point $(98 \%-99 \%)$. The effective radii ( $\left.r_{\text {eff }}\right)$ of the aerosols decrease as the relative humidity increases for maritime and also there are good linear relationship between Kelvin radii and bulk hygroscopicity for continental. Finally it discovered that, Kelvin radii for mass based is greater than that of volume based $\left(A_{m}>A_{v}\right)$. Meanwhile the bulk hygroscopicity for mass based is less than that of volume based $\left(\mathrm{B}_{\mathrm{m}}<\mathrm{B}_{\mathrm{v}}\right)$.

\section{REFERENCES}

Bilde, M. and Svenningsson, B. (2004): CCN activation of slightly soluble organics: the importance of small amounts of inorganic salt and particle phase, Tellus B, 56, 128-134, 2004.

Broekhuizen, K., Kumar, P. P., and Abbatt, J. P. D. (2004): Partially soluble organics as cloud condensation nuclei: Role of trace soluble and surface active species, Geophys. Res. Lett., 31(1), L01107,doi:10.1029/2003GL018203,.

Hess M., Koepke P., and Schult I (1998), Optical Properties of Aerosols and Clouds: The Software Package OPAC. Bulletin of the American Meteorological Society, 79, 5, 831-844. 
Jacobson, M. Z.(2001): Strong radiative heating due to the mixing state of black carbon in atmospheric aerosols, Nature, 409, 695-697.

Kawana, K., Kuba, N., Mochida, M., (2014). Assessment of cloud condensation nucleus activation of urban aerosol particles with different hygroscopicity and the application to the cloud parcel model. J. Geophys. Res. 119, 3352-3371

Kohler, H (1936), The nucleus and growth of hygroscopic droplets, Trans. Faraday Soc., 32, 1152-1161.

Liu, X., Gu, J., Li, Y., Cheng, Y., Qu, Y., Han, T., Wang, J., Tian, H., Chen, J., Zhang, Y., (2013). Increase of aerosol scattering by hygroscopic growth: observation, modeling, and implications on visibility. Atmos. Res. 132-133, 91-101.

Maßling, A., Wiedensohler, A., Busch, B., Neusuß, C., Quinn, P., Bates, T., Covert, D., (2003). Hygroscopic properties of different aerosol types over the Atlantic and Indian Oceans. Atmos. Chem. Phys. 3, 1377-1397.

Meyer, N. K., Duplissy, J., Gysel, M., Metzger, A., Dommen, J., Weingartner, E., Alfarra, M. R., Prevot, A.S. H., Fletcher, C., Good, N., McFiggans, G., Jonsson, A. M., Hallquist, M., Baltensperger, U., and Ristovski, Z.D. (2009): Analysis of the hygroscopic and volatile properties of ammonium sulphate seeded and unseeded SOA particles. Atmospheric. Chemistry and Physics, 9, 721-732, doi:10.5194/acp-9-721-2009.

Mikhailov E., Merkulov V, Vlasenko S., Rose D., and P"oschl. U.,(2011). Mass-based hygroscopicity parameter interaction model and measurement of atmospheric aerosol water uptake. Atmos. Chem. Phys., 2011, doi:10.5194/acpd-11-30877-2011

Ogren, J.A., Charlson, R.J., (1992). Implications for models and measurements of chemical inhomogeneities among cloud droplets. Tellus B 44, 208-225.

Petters, M. and Kreidenweis, S.: (2007) A single parameter representation of hygroscopic growth and cloud condensation nucleus activity. Atmospheric Chemistry and Physics, 7, 19611971, doi:10.5194/acp-7-1961-2007,

Pruppacher, H. R. and Klett, J. D.( 2000): Microphysics of clouds and precipitation, Kluwer Academic Publishers, Dordrecht, The Netherlands.

Raymond T. M. and Pandis S. N.( 2002): Cloud activation of single-component organic aerosol particles, J. Geophys. Res., 107, 4787, doi:10.1029/2002JD002159,.
Raymond, T. M. and Pandis, S. N.( , 2003): Formation of cloud droplets by multicomponent organic Particles, J. Geophys. Res., 108, 4469, doi:10.1029/2003JD003503.

Randles , C. A. , Russell L. M. and. Ramaswamy V. (2004). Hygroscopic and optical properties of organic sea salt aerosol and consequences for climate forcing. Geophysical Research

Letters, 31, L16108, doi:10.1029/2004GL020628.

Saxena, P., Hildemann L. M., McMurry P. H., and Seinfeld J. H. (1995). Organics alter hygroscopic behavior of atmospheric particles, Journal of Geophysical Research, 100(D9), 18,75518,770 .

Seinfeld, J. H. and Pandis, S. N.( 2006), Atmospheric Chemistry and Physics: From Air Pollution to Climate Change, John Wiley and Sons, Inc., New York, USA.

Solomon, S., D. Qin, M. Manning, Z. Chen, M., and Marquis, K. A., M. Tignor, and H. Miller (2007). Climate Change 2007: The Physical Science Basis. Contribution of Working Group I to the Fourth Assessment Report of the Intergovernmental Panel on Climate Change., Cambridge University Press, Cambridge, United Kingdom and New York, NY, USA.

Stokes, R. H. and Robinson, R. A. (1966). Interactions in aqueous nonelectrolyte solutions. I. Solute-solvent equilibria. Journal of Physical Chemistry, 70, 2126-2130.

Stock M., Y. F. Cheng, W. Birmili, A. Massling, B. Wehner, T. Muller, S. Leinert, N. Kalivitis,N. Mihalopoulos, and A. Wiedensohler, (2011). Hygroscopic properties of atmospheric aerosol particles over the Eastern Mediterranean: implications for regional direct radiative forcing under clean and polluted conditions. Atmospheric Chemistry and Physics., 11, 42514271, $\quad$ www.atmos-chem-phys.net/11/4251/2011/ doi:10.5194/acp-11-4251-2011

Swietlicki, E., Hansson, H.-C., H“ ameri, K., Svenningsson, B., Massling, A., McFiggans, G., McMurry, P. H., Pet” aj “" a, T., Tunved, P., Gysel, M., Topping, D., Weingartner, E., Baltensperger, U., Rissler, J., Wiedensohler, A., and Kulmala, M.( 2008): Hygroscopic properties of submicrometer atmospheric aerosol particles measured with H-TDMA instruments in various environments: a review, Tellus B, 60, 432-469,

Tang, I.N., (1996). Chemical and size effects of hygroscopic aerosols on light scattering coefficients. J. Geophys. Res. 101, 19245-19250.

Tijjani B.I., Galadanci G.S.M. Abubakar A.I. Koki F. S. Adamu I. D., Nura A. M. Saleh M., Uba S.(2015), The effect of kelvin 
effect on the equilibrium effective radii and hygroscopic growth of atmospheric aerosols. Journal of Natural Sciences Research,ISSN 2224-3186 (Paper), Vol.5, No.22,

Twomey, S.( 1977): Atmospheric Aerosols, Developments in Atmospheric Science, Elsevier, New York, USA,.

Wang, Y., Zhang, F., Li, Z., Tan, H., Xu, H., Ren, J., Zhao, J., Du, W., Sun, Y., (2017). Enhanced hydrophobicity and volatility of submicron aerosols under severe emission control conditions in Beijing. Atmos. Chem. Phys. 17, 5239-5251.

Zieger P., Fierz-Schmidhauser R. Weingartner E., and Baltensperger U. (2013), Effects of relative humidity on aerosol light scattering: results from different European sites, Atmos. Chem. Phys., 13, 10609-10631, doi:10.5194/acp-13-106092013.

Zhang, F., Li, Y., Li, Z., Sun, L., Li, R., Zhao, C., Wang, P., Sun, Y., Liu, X., Li, J., Li, P., Ren, Sjogren, S., Gysel, M., Weingartner, E., Baltensperger, U., Cubi-son, M. J., Coe, H., Zardini, A. A.,Marcolli, C., Krieger, U. K., and Peter, T.( 2007): Hygroscopic growth and water uptake kinetics of twophase aerosol particles consisting of ammonium sulfate, adipic and humic acid mixtures. Journal of Aerosol Science, 38, 157171 .

Zhang, F., Wang, Y.Y., Peng, J.F., Ren, J.Y., D, C., Zhang, R.Y., Sun, Y.L., Yang, X., Li, Z.Q., (2017). Uncertainty in predicting CCN activity of aged and primary aerosols. $J$. Geophys. Res.: Atmosphere 122 (11) 723-711,736. 